\title{
The Spreading of the City Improvement District Model in Johannesburg and Cape Town: Urban Regeneration and the Neoliberal Agenda in South Africa
}

\author{
SOPHIE DIDIER, ELISABETH PEYROUX, MARIANNE MORANGE
}

\author{
http://www.ijurr.org/article/the-spreading-of-the-city-improvement-district-model-in- \\ johannesburg-and-cape-town-urban-regeneration-and-the-neoliberal-agenda-in-south-africa/
}

\begin{abstract}
The spreading of CIDs and connected forms of public-private partnership as an international model of urban renewal has been linked to the rise of 'urban entrepreneurialism' and the neoliberalization of policies and practices, at a time when competition between cities in the global economy has never been greater. The aim of the authors in this article is to explore the transfer and adaptation of the CID model in two cities of the South, Johannesburg and Cape Town. They argue that CIDs are an example of the local embeddedness of neoliberalism. They highlight the role of the private sector in importing and adapting CIDs in South Africa, and point out the rise of techno-politicians in CID management. Paying particular attention to discourses, they analyse the way images of decaying urban centres were used to legitimate the adoption of such schemes. The subsequent transformation of the model enables them also to explore the specificity of the adoption of this international best practice model in South Africa and its further circulation at the Southern African level: while CIDs in South Africa raise familiar North American issues regarding the private management of public spaces, they also question the very nature of the African city model proposed and envisioned locally.
\end{abstract}

\section{Introduction}

Much as was the case in European and North American cities, business improvement districts (BIDs) have been broadly adopted in South African cities under the name city improvement districts (CIDs) since the mid-1990s. While the designations and organizational and decisionmaking structures of BIDs vary according to geographical contexts (Hoyt, 2005), South African CIDs share a set of key principles with their North American and European counterparts: they represent a form of business and landowners' organization at the neighbourhood level, dealing with the provision of additional services in order to improve commercial and residential areas in decline. They derive their funding from additional taxes (top-ups) levied from these same owners (Berg, 2004; Morange and Didier, 2006a; Dubresson, 2008), and rely on the doxa of public-private partnership. They have proven popular in all major cities of the country, i.e. Johannesburg, Durban and Cape Town, as well as in smaller metropolitan areas, e.g. Pretoria, Port Elisabeth and Nelspruit.

The growing international body of literature documenting BIDs has studied them as urban regeneration tools (Hoyt, 2005; 2006; Lloyd et al., 2003), and, owing to their common focus on providing private security services, as an instrument of policing and control (Eick, 2007; Marquardt and Füller, 2003; Lippert, 2009). Scholars have largely emphasized the changing forms of urban governance underlying the implementation of BIDs and the ways in which they influence policy making (Wolf, 2006; Morçöl and Zimmermann, 2006; Cook, 2009). Analyses have ranged from an assessment of their efficiency (Hoyt, 2004) to critical analyses underlining 
Didier S., Peyroux E., Morange M., 2012, “The spreading of the City Improvement District model in Johannesburg and Cape Town : Urban regeneration and the neoliberal agenda in South Africa", The International Journal of Urban and Regional Research, 36(5), pp. 915-935.

their implications in terms of inequalities and exclusion, mostly in the context of the neoliberalization of urban policies in North America and Europe (Zukin, 1995; Briffault, 1999; Mitchell, 2001; Nahnsen, 2002; Töpfer et al., 2007). Analyses dealing with the declination of the model in cities of the South remain rare, and have not specifically tackled the issue of circulation itself, as with European case studies for Britain (Ward, 2006; Cook, 2008; McCann and Ward, 2010) or Germany (Pütz, 2008). In the case of South African CIDs, specific aspects have been documented, such as security governance with regards to policing issues (Berg, 2004), their integration into local economic development (LED) schemes (Rogerson, 1996), or the way they fit neoliberal or entrepreneurial strategies with a focus on their governance structure (Dubresson, 2008; Miraftab, 2007; Murray 2008; Peyroux, 2008; Didier et al. 2011).

The development of CIDs in South African cities deserves closer analysis from this point of view. The transfer can indeed be read as part of the much wider neoliberalization of urban practices and policies in South Africa - and is often seen as imposed from the North. Yet, as Ward (2006) pointed out for Britain, what is at stake in the policy-transfer process of this North American model, is not just the export power of the formula, but the willingness of the local level to adopt it regardless of the possible difficulties arising during its adaptation. To quote Peck: "no transition to neoliberalism was ever solely an "inside job", nor was it just an "external imposition" ..., for this is a locally embedded yet transnational process' (Peck, 2004: 395). We believe the South African case to be a significant example of this tension, which over time gives way to hybridization, and that it could hence empirically document theoretical literature about the circulation of the policies and practices of neoliberalism in answer to the calls of authors such as Larner (2003), who ask for place-based and nuanced assessments of neoliberalism. Neoliberalism is never indeed manifested in a pure form (Brenner et al., 2010) and is also characterized by its capacity to hybridize with inherited institutional landscapes and other types of policies and regulations: the South African CID case offers, in this sense, an interesting window on the nature and timeline of these hybridization processes.

Indeed, while reference points in the definition of neoliberal policies for urban management may be international, neoliberalization is, at the same time, a strongly path-dependent process (Brenner and Theodore, 2002). We need to address the specific historical and political context that shapes its reception, as well as the difficulties arising from the adoption of such an international model in post-apartheid South Africa and the demands of its people for socially sensitive urban policies. Furthermore, the neoliberalization of urban practices has to be understood as a social phenomenon, constructed, amended and promoted by networks of stakeholders and, therefore, open to change and contestation articulated by its host society [F1] (Leitner et al., 2007). Indeed, CIDs have been in use in South Africa for 15 years now, a period long enough to offer some interesting insights into their evolution and their discursive reformulation over time, notably under pressure from the local political context (see also Peyroux, forthcoming). The first part of the article will therefore document the initial import process that took place in South Africa within a very specific timeframe generally identified as a neoliberalization phase of urban policies in Johannesburg and Cape Town. With the implementation of CIDs, both cities adopted a 'best-international-practice' model, analysed here as one of the many tools that give shape to neoliberalization. The analysis will focus first on the justifications offered and the timeframes within which this neoliberal turn took place. Nevertheless, although the imported model and its references were the same in the two cities, there were major differences in which they were adapted locally and, most of all, in the ensuing spread of the formula throughout the metropolitan space after its initial implementation in the 
Didier S., Peyroux E., Morange M., 2012, “The spreading of the City Improvement District model in Johannesburg and Cape Town : Urban regeneration and the neoliberal agenda in South Africa”, The International Journal of Urban and Regional Research, 36(5), pp. 915-935.

city centre. At the intra-metropolitan level, the model was reterritorialized as well (see Figures 1 and 2).

Yet, the question of the local embeddedness of neoliberalism with regard to the global circulation of policies and practices remains to be addressed. Indeed, much as was the case with the United Kingdom (Ward, 2006; Cook, 2008), a consistent trait in the reception of 'bestinternational-practice' models is a blurring of the specificities of the local context in the initial phase of implementation, paving the way for a seamless transfer of foreign policies and practices. Yet, the model was not adopted as smoothly as the official history of CIDs in South Africa would suggest; once the initial implementation was done, the scheme kept evolving, notably under critical pressure from the local civil society and changes of global policy at national and local government levels. The second part of the article will thus reflect on the transformations that took place following the adoption of the model in South Africa, in tune both with broader debates discussing the role of city centres in the general architecture of the South African metropolises, and also with an emerging decentring of the models in their progress from the North to the South.

\title{
CIDs and the neoliberalization of urban management practices in Johannesburg and Cape Town
}

\begin{abstract}
Since its establishment in November 2000, Cape Town's Central City Improvement District (CCID) has become an internationally-acclaimed model of partnership between local authorities and local businesses .... The establishment of the CCID followed an extensive user research project conducted in the Central City of Cape Town, which identified crime and grime as the two major disincentives to investment, public confidence and development in the area. Arising out of these findings, international research revealed that the most frequently and successfully used model for city centre revitalization was the City Improvement District (CCID report 2005 — fifth anniversary of the Cape Town Central CID).
\end{abstract}

The adoption of the CID model in South Africa which, from this promotional statement, seems rather simple and straightforward, took place over a roughly 15 -year period, in a context of the neoliberalization of urban policies and practices as well as that of the democratic transition. Much has been written about the neoliberalization process. In its urban dimension, most of the body of literature comes from the 'ideological heartland' of neoliberalism (the USA and UK) (Larner, 2003), although neoliberalism and its principle of 'less government, more governance' comes in all shapes and sizes (Peck and Tickell, 2002; Peck, 2004; Zunino, 2006). While South African cities experienced a 'lemming-like rush towards urban entrepreneurialism' (Peck and Tickell, 2002: 385) since the beginning of the 1990s, they were affected by neoliberalism in their own specific way and timeframe: following the dismantling of apartheid, public policies at national level have radically shifted from their initial focus on redistribution embodied by the RDP (Reconstruction and Development Program), aiming at erasing apartheid's inherited urban inequalities, to the implementation of the neoliberal-inspired Growth, Employment And Redistribution programme (GEAR) of 1996. Since the 2005 adoption of the Accelerated and Shared Growth Initiative (ASGI-SA) scholars have debated whether South Africa is shifting away from neoliberal policies towards the achievement of the 'developmental state' (Fine et al., 2010) [F2].

This national orientation has implications for local authorities. While urban policies have been tailored at the local level since 2000 by newly established powerful metropolitan governments, urban policies, and in particular cities' strategies, are informed by national and provincial strategies and are required to align their objectives with broader ones. True to the neoliberal 
Didier S., Peyroux E., Morange M., 2012, “The spreading of the City Improvement District model in Johannesburg and Cape Town : Urban regeneration and the neoliberal agenda in South Africa”, The International Journal of Urban and Regional Research, 36(5), pp. 915-935.

agenda, urban policies have been affected by the process of devolution and the privatization of various service provisions, as well as by a widely debated redefinition of metropolitan powers in terms of economic development (Parnell and Pieterse, 1999; Robinson, 2006). In addition, this delegation complemented a commitment at the metropolitan level to redress imbalances in terms of service delivery in the townships, a backlog seriously burdening city budgets in the country (Seekings, 2000). The CID formula, as micro local tool of urban management, perfectly fitted the bill of the city centres while also meeting the changing imperatives placed upon cities in South Africa's economic planning (Lipietz, 2008).

\title{
Institutional implementation: the private sector to the rescue and the rise of 'technopoliticians'
}

\begin{abstract}
Businesses and investors in the inner city have a direct interest in securing sound policies, effective institutions and efficient management of the public urban environment. International experience has clearly demonstrated that the business sector is critical in achieving these ends but, to have a decisive impact, it must be well organized and willing to invest resources. To this end the Johannesburg Inner City Business Coalition was established (1988) with its mission 'to ensure economic growth and the revitalization of the urban environment so as to ensure the improvement of the quality of life for all city stakeholders and role players

(The Johannesburg Inner City Business Coalition,

http://www.joburgcentral.co.za/jicbc.php (accessed in July 2007)).
\end{abstract}

The most commonly underlined aspect of neoliberalization in the city consists in the institutional restructuring of public authorities and the growing power of the private sector in urban affairs (Brenner and Theodore, 2002). On the South African urban scene, this trend was illustrated by increasing devolution of the provision of major city services in a context of growing municipal autonomy and a commitment to ensure the equitable provision of basic services to all residents (McDonald and Smith, 2005). The degree of privatization varies from one sector to another, as well as from one city to another: in Johannesburg, it took the form of the corporatization of most major aspects of the city's public services, through the creation of utilities (electricity, water, sanitation and waste management) and agencies (roads and parks among others) (Mabin, 2007).

Such processes are supported by a proliferation of beyond-the-state entities, which Jessop described as 'growing reliance on partnership, networks, consultation, negotiation, and other forms of reflexive self-organization' (Jessop, 2002: 460). Partnership is instituted as a capital rule of the new order, and is verbally supported as the only possible way forward, what Peck (2004: 394) calls the 'politics of inevitability', in a pragmatic approach praising multi-agent cooperation and a submetropolitan scale of intervention (Bénit-Gbaffou et al., 2008).

CID structures work as a good example of these governance arrangements and their ideological implications (Peyroux, 2008). Their association of business leaders, city officials and civil society representatives is ideologically supported by a discourse from private stakeholders subtly pointing out the inefficiency of the public authorities and consequently the fact that urban affairs should be handled in cooperation with the private sector: reflecting on a declaration by a former Mayor of New York City praising the BID formula, the then executive director of the Central Johannesburg Partnership (CJP) [F3] declared: 'That's a ringing endorsement for the private urban management model from the leader of one of the world's great cities!'. [F4]

This pro-business approach is believed to match the public sector's lack of capacity to implement efficient regeneration strategies. Quoting an article researching the formation of 
Didier S., Peyroux E., Morange M., 2012, “The spreading of the City Improvement District model in Johannesburg and Cape Town : Urban regeneration and the neoliberal agenda in South Africa", The International Journal of Urban and Regional Research, 36(5), pp. 915-935.

BIDs in the USA, the Business Plan of the Central Improvement District in Johannesburg emphasized that '[i]n spite of enormous public investment in infrastructure and transportation systems in downtowns, local governments generally lack the resources and political will to save them on their own' (CJP, 2001: 22). The private sector's efficiency may eventually be acknowledged and reinforced by public authorities themselves, successfully pushing for its further involvement. The dominant tendency to measure public action and efficiency in terms of accountability also lies at the heart of the notion of partnership promoted by these new forms of urban management. The constant weighing and judging is furthermore made public through powerful media divisions set up by the partnerships: for instance, Neil Fraser, former head of the CJP reflected on 'good' and 'bad' experiments in terms of urban management in the city:

Over the next four to five weeks I want to look critically at how the inner city has done during 2004 and then to do some crystal-ball gazing for 2005 and beyond. It's also a good time to award some brickbats and bouquets or orchids and onions, roses or cabbages — none of which sound very cityish but you know what I mean! (Fraser, 2004).

When one reflects on the official (and somewhat complicated) chronology of the adoption of the CID model in both cities, one has to admit that public authorities seem to have lagged behind the private sector, seeing that CIDs originally appeared in the South African landscape as informal private initiatives. In Cape Town, the recognition of the city centre crisis did not occur immediately after the first democratic local government elections (in 1995), nor did it come from the City's officials. According to Nahnsen (2002: 150), the publicization of the sense of decay justifying the setting up of the first CID in 1999 was relayed via the local press around 1998-1999, at precisely the time when the Central CID was implemented. This discourse heavily pointed up the incompetence of public authorities when it came to managing the central city and relied as well on the Johannesburg case, exemplifying a city centre gone bad and thus able to be used as a striking bogeyman. The Cape Town public press campaign to save the city from becoming another Johannesburg helped push the implementation of innovative and rather hastily designed schemes: the general state of Johannesburg's city centre during the 1990s, highly publicized worldwide, seemed to epitomize the type of urban problems a CID can cure, a mix of vacancy, decay, informal trade and, of course, crime (see Morris, 1999; Tomlinson, 1999; Guillaume, 2001; Beavon, 2004).However, this rather belated realization and outcry about urban decay complemented behind-the-scene lobbying by the most powerful representatives of the business and real estate community, e.g. the South African Property Owners Association and the Cape Chamber of Commerce and Industry at the City Council to address the issues of urban decay and crime in the centre. Similarly, in Johannesburg, informal associations of business and property owners at neighbourhood level preceded the implementation of their formal counterparts since no legal framework for CIDs existed prior to the Provincial legislation that became effective in 1999 [F5]: this historical fact could easily pass as proof of the clear-sighted vision of the private sector and is often put forward by the private entities managing the CIDs, as exemplified by the Braamfontein Improvement District where corporate property owners are presented as the leaders of public environment upgrading (see http://www.braamfontein.org.za, as of April 2007).

The private sector's claim that their discovery and development of CIDs was the starting point in the saving of decaying neighbourhoods is nevertheless at odds with the chronology of local strategic planning in South African cities: the fact that public authorities did not initiate CIDs does not mean they did not care about central city decay, or were not aware of it, they only used different tools to try to remedy it. In Johannesburg, in view of the worrying economic performance as well as the rise of unemployment and poverty levels, they actively embraced 
Didier S., Peyroux E., Morange M., 2012, “The spreading of the City Improvement District model in Johannesburg and Cape Town : Urban regeneration and the neoliberal agenda in South Africa", The International Journal of Urban and Regional Research, 36(5), pp. 915-935.

urban renewal strategies as early as the mid-1980s, in a context of challenges brought by globalization and growing contestation of the apartheid regime (Rogerson, 1996). Ever since the 1995 democratic elections, Local Economic Development (LED) has been a recurrent central item on the city's agenda as exemplified by the drafting process of the 'Joburg 2030' framework (Parnell and Robinson, 2006; Lipietz, 2008), with a general view that growth at the local level would generate redistribution. Similar concerns in Cape Town led to the early attempts at regenerating the city centre, beginning with the pedestrianization and revamping of St. George's mall in the late 1980s. The constant naggings (often turning to the benefit of the private sector) over who was the first to implement urban regeneration is a good illustration of the power equilibrium at play within PPPs: while the façade is one of cooperative arrangements, of a win-win solution for all parties, in line with the objectives and the means to attain them that are shared between the stakeholders, different cultures remain and can occasionally resurface in public. This should nevertheless not take the attention away from one of the most interesting traits of these new arrangements backing the set-up of CIDs in South Africa: the birth of a new breed of 'technopoliticians'. As Zunino suggested in the case of Chile, these 'flexible public workers now replace the old bureaucracy: professionals with short term contracts or acting as part-time advisors or consultants' (Zunino, 2006: 1835). They navigate between public and private sectors as was seen in the City of Cape Town: the first CID, the Central City Improvement District (CCID), was set up in 2000 by the Cape Town Partnership (CTP), a non-profit structure dominated by local business interests resulting from the joint initiative of the South African Property Owners Association (SAPOA) and the Regional Chamber of Commerce and Industry. The CJP was very active in the writing of a unified municipal bylaw on CIDs in 2003 that was in the end the joint effort of a city official and a private consultant. The same type of crossover was found in Johannesburg where the CJP participated in the drafting of the CID legislation and Kagiso Urban Management (KUM, now renamed Urban Genesis), the company responsible for the management of several CIDs, offered its services to would-be CID areas in these terms: "We have an exceptional knowledge of legislation and processes related to city improvement districts because we have been responsible for much of the drafting and legislation and subsequent implementation thereof.' [F6] KUM even emphasized its proximity to and cooperation with the local government by stressing its role as intermediary or facilitator: 'Managing the relationship with the city' (on utilities, law enforcement, informal trade management, taxi management, planning and community areas of concern) has become one of the 'typical CID services' provided by the company [F7]. For instance, KUM was appointed 'Agent Council' and mandated to collect the CID levies directly from the property owners, covering de facto for the municipality. [F8]

In a sense, despite some forms of competition between public and private actors, government and the private sector share the same set of objectives as well as a closeness that shows that the line between public and private becomes increasingly blurred and porous (Peck, 2004: 397).

\section{The shop window effect as the ideal public/private strategy}

Spatially, the designation of 'shop windows' within metropolitan areas (Bénit and GervaisLambony, 2005) where CIDs are implemented is consistent with the new territorialized planning orientations of LED endorsed by the metropolitan powers: such designated areas would and should work as economic and fiscal catalysts for the entire metropolis. This is particularly true of the 2000-2007 period, when municipal priorities turned almost solely towards LED: for instance, the creation of the Johannesburg Development Agency (JDA) in 2001 appears emblematic of this shift, with its focus on creating an efficient business 
Didier S., Peyroux E., Morange M., 2012, “The spreading of the City Improvement District model in Johannesburg and Cape Town : Urban regeneration and the neoliberal agenda in South Africa", The International Journal of Urban and Regional Research, 36(5), pp. 915-935.

environment and upgrading areas in decay. [F9] This period saw the formalization of informal tools of urban renewal such as CID-like schemes by means of provincial and municipal bylaws drafted in both cities, illustrating the fact that the window of opportunity for micro local informal experiments such as CIDs to develop in the mid-1990s rapidly gave way to an official endorsement. Indeed, the municipal strategies of the late 1990s intersected those of the business sector, notably the real estate industry, eager to see the drop in property values come to a halt (see the role of the annual Rode Report on the property industry, which publicized the settingup of the CID in Central Cape Town in 2000).

Within this broad framework, the early implementation of the city centre CIDs of Cape Town (2000) and Johannesburg (the first 'voluntary CID' [F10] was introduced as a pilot project in the CBD in 1993, while full backing from the municipality came around 2000) comes as no surprise. In Cape Town, the importance of the central city's economic activities to the well-being of the metropolitan area, as well as the tourism strategies attached to it, seemed sufficient reasons to push for the implementation of the forerunner of the CID experiments in the city. The inner city of Johannesburg is also an important and productive economic asset (although a significant proportion of business shifted to the northern suburbs) and it houses an estimated 200,000 inhabitants (City of Johannesburg, 2004).

Another reason for municipalities to push for the implementation of area-based renewal schemes in city centres lay in the drop in property taxes experienced in these areas after the end of apartheid. In central Cape Town, between 1995 and 2003, property values declined by more than $60 \%$ [F11], at a time when general property values rose. In particular, 2001 was a black year, when the reassessment of property values led to an alleged 50\% downscaling of innercity tax returns. Johannesburg also experienced a significant drop in tax returns during the 1990s from deteriorating properties in the CBD and long-term vacant space in older office buildings (Rogerson, 2004). Moreover, as a self-financing mechanism for delivering services within restricted areas, CIDs provided cash-strapped municipalities with opportunities for upgrading and enhancing public spaces without burdening city budgets, a solution much appreciated by the public authorities: the local government of Johannesburg was in a state of continuous fiscal crisis from the end of 1980s (Beall et al., 2002), and this situation led directly to the restructuring period in 1997, when the City was placed under administration (Robinson, 2006). This situation could explain why the day-to-day delegation of urban management to the CIDs has appealed to public authorities. This delegation was also presented as a way for local authorities to focus their resources on the townships and their backlog in terms of service delivery, yet all CIDs function as mere 'top-up' mechanisms, meaning the City is bound by service level agreements to deliver a minimum standard of service in these areas. The public endorsement of CIDs usually overlooks the fact that collecting an additional levy and ringfencing CID expenditures contradict the 'One city one tax base' anti-apartheid motto, i.e. the general principle of balancing out between rich and poor, formerly Black and White areas, when it comes to fiscal responsibility.

\section{Multiplying CIDs in both cities}

The CIDs in the city centres of Cape Town and Johannesburg are today old phenomena. Their initial success was heavily publicized in relation to security issues: in Cape Town, as early as 2002 , the CTP boasted in press releases that crime incidence had dropped by $60 \%$ during the CCID's two years in operation [F12]. Yet, if 'Crime and Grime' appeared to be curbed, the influence of CIDs on renewed investment in the centre seemed more difficult to assess in 
Didier S., Peyroux E., Morange M., 2012, “The spreading of the City Improvement District model in Johannesburg and Cape Town : Urban regeneration and the neoliberal agenda in South Africa", The International Journal of Urban and Regional Research, 36(5), pp. 915-935.

Johannesburg, which suffered severely from capital flight to suburban nodes like Sandton during the 1990s, what the business press in the early 2000s called 'an exodus' [F13] of the business community. However, more recent trends in land and housing markets, in particular declining office vacancies, rising residential rents and the launch of residential schemes targeting middle- to higher-income groups tend to show some positive signs of recovery.[F14].

The image of success attached to the CID formula, carefully built between 1993 and 2000 by the PR divisions of the CIDs' managing bodies as well as by PPPs (the Central Johannesburg Partnership in Johannesburg and the Cape Town Partnership in Cape Town), paved the way for the spread of CIDs to other areas of the city, where the formula was amended according to the strategies at play. This is particularly true of Johannesburg, where CIDs were launched as early as 1998 in the very suburban nodes (Sandton in particular) that contributed to the decline of the centre's economic leadership. With this shift to the suburbs, tasks such as 'district branding' became prominent in these CIDs (Peyroux, 2008), confirming the recentring of the formula at that time to fit the strategies of the business sector for the most part[F15]. The process also confirms the full endorsement of the CIDs by local public authorities and their affiliates, e.g. the JDA. The setting up of residential CIDs in the inner-city's low-income, overwhelmingly African [F16] and high-density neighbourhoods (Berea, Hillbrow) in the mid-2000s similarly shows the leading role in these regeneration initiatives of a handful of private property development companies.

The difference between Johannesburg and Cape Town with regards to CID strategies needs to be stressed, for their respective weight in terms of economic power echoes not only the structures of the two metropolises, but also the racial divides in the two cities. In Cape Town, the power of suburban CIDs could never match that of the CBD, and the economic scope of suburban nodes is still tentative. The budget of the largest suburban CID is six times less than that of the CBD (City of Cape Town, 2004). Moreover, the shift from city centre to residential suburbs was accompanied by a shift in the nature of the CIDs, until the metropolitan authority reasserted its power over these experiments in 2003. Residential CIDs were then mostly terminated or their planning phase halted (Durbanville and Pinelands), and the city focused on business-oriented CIDs, e.g. Airport, Parow, and Epping industrial areas. CIDs with a strong residential base such as Green Point, Oranjekloof or Woodstock are still tolerated since they fit the Unicity's economic development strategies for the City Bowl encompassing both the CBD and the inner city areas targeted for development through international investments, tourism and the film industry (Morange and Didier, 2006a), or when they fit the overarching national policy of community policing in the affluent or middle-class (mostly White) southern suburbs (Rondebosch and Groote Schuur). The mushrooming of CIDs in Johannesburg, as well as the endorsement of the formula by the municipality (although with reservations regarding the spreading of CIDs in middle-class suburban residential areas), which did not lead to a political reassertion à la Cape Town, might also point to the dominant position of the business community in the economic capital (see Bénit-Gbaffou et al., 2008): the great flexibility of initiation and implementation of CIDs in Johannesburg fuels this interpretation as well. The main areas targeted then jointly fitted the business sector's interests (the suburban nodes, with their business CIDs) and the emphasis placed by the municipality on the regeneration of the (now mostly African) broad inner city (which now hosts a combination of older business CIDs and residential CIDs recently implemented). 
Didier S., Peyroux E., Morange M., 2012, “The spreading of the City Improvement District model in Johannesburg and Cape Town : Urban regeneration and the neoliberal agenda in South Africa", The International Journal of Urban and Regional Research, 36(5), pp. 915-935.

\title{
'World class African city'? What 'world class African city'?
}

\section{Discussing CIDs in the specifically South African context}

\begin{abstract}
The city improvement district model is based on international best practice. It is aimed at preventing the degeneration of cities and towns and the consequential urban decay, and facilitating their upliftment, economic growth and sustainable development.

(City of Cape Town (2003), quoted in Berg (2004)).
\end{abstract}

The adoption of the CID formula not only underlines changes in South African urban management per se, it also raises questions with regard to the very nature of the best practice model itself. What does it mean for a South African city to adopt such a formula explicitly modelled after Western experiments? In this chapter, we will explore this international dimension, the way it crops up in the discourse and practices of CID proponents, but also the way it can blend in or be at odds with South African urban debates. In doing so, we hope to further the study of a more place-based analysis of neoliberalization and its practices (Larner 2003), and show the sometimes problematic local adaptation of such best practice models.

\section{Transfer networks and the origin of the CID model: international best practice in motion}

The adoption of the CID formula in both cities followed a similar pattern of a private initiative later acknowledged and backed by the public sector. The reference point, in both cases, consisted in previous experiments deemed successful on the international planning scene. Central CID officials in South Africa offer the same narrative of the 1990-2000 period as their British counterparts, involving numerous field trips to New York and Philadelphia, whose experiments were also central in the United Kingdom's implementation of a national CID policy (Ward, 2006). Miraftab (2007: 12) interestingly argues that the CID implementation strategy in central Cape Town meets local urban and planning fantasies associated with a dominant colonial culture, whose reference point remains the homeland metropolis. Indeed, references to New York and London crop up in the public discourse on the wished-for future as far as South African city centres [F17] are concerned. When it comes to CIDs per se, New York has been regularly used as a reference amongst key South African proponents of the formula: for instance, Dereck Bock, Cape Town Central CID former security manager, once quoted Rudolph Giuliani as a role model [F18], in view of the success of his internationally advertised 'zero-tolerance' policy against crime. The numerous references to New York obviously reflect the importance of this city in the global imagination, but not just in terms of colonial mimicry: in the new neoliberal world order, reference points and actually existing models are very few, and Manhattan, when it comes to security issues, is probably the most important one thanks to Giuliani's much publicized handling of public affairs and security. Significantly, the CTP's recent rewriting of the early history of local CIDs points to the global availability of American BID experiences at the time (CTP, 2009). In the case of CID policy transfer, the most famous American BIDs (Times Square in particular, see Zukin, 1995; Ward, 2006) were also used as a reference point and benchmark, regardless of the relevance of the implicit comparison between them and their South African counterparts (see Ward, 2006 for a similar analysis as regards British BIDs, and Tomlinson, 1999): Downtown Baltimore, Central Houston, Downtown Portland and Downtown Denver were quoted in the early business plans of Johannesburg's CIDs, which praise their respective success with regard to crime, community development, refuse collection, etc. When mentioned in the business press, the references were usually condensed to the more emblematic (albeit vague) example of New York's success: 
Didier S., Peyroux E., Morange M., 2012, “The spreading of the City Improvement District model in Johannesburg and Cape Town : Urban regeneration and the neoliberal agenda in South Africa”, The International Journal of Urban and Regional Research, 36(5), pp. 915-935.

Improvement Districts are still a new and uncertain idea in South Africa, despite the fact that they have been operating for several years in America and Europe. The arrest in New York's declining situation reflected in street crime, property values and rentals, cleanliness and local services is usually attributed to the implementation of CIDs.[F19]

More importantly, the local adoption of international best practice is pushed through powerful international networks. For instance, reference to the International Downtown Association (IDA), an American private entity the purpose of which is to revitalize city centres worldwide, is still constant in South African CID proponents' narratives, either as a starting point or a later benchmark and powerful tribune for the publicization of South African CID results (see Box 1): local proponents of the CID formula rely heavily on their international expertise to introduce the concept to public authorities, as was the case when the CJP and the IDA organized a tour of US BIDs in 1996 to convince Johannesburg's public authorities. The global connections of our local urban managers are very important, and could also be read as a form of legitimization after apartheid's decades of international isolation: the initial field trips are nowadays followed by permanent contacts with CID managers abroad, as well as academic connections [F20].

\begin{abstract}
Box 1: Neil Fraser, a well-connected director
'The past three weeks has in fact seen a surge of interest in South African and local City Improvement Districts from a variety of sources. It started with a visit from Prof. Lorlene Hoyt, Assistant Professor of Technology and Planning from the Massachusetts Institute of Technology (MIT). Lorlene was here as part of a research programme on Improvement Districts internationally.[F21] Then a week later I lunched with my good friend Alan Tallentire and his wife Nicola and was updated on the development of Improvement Districts in the UK. Alan is the chief executive of the Association of Town Centre Management[F22] in London. He confirmed that the British Government is in the process of drafting legislation to facilitate improvement districts in British towns and cities. Alan anticipates that about 30 of these will be operational by March next year. This week I was visited by researchers from the CSIR also looking at the CID model.[F23] So the focus is on CIDs at the moment.'
\end{abstract}

Source: January 2003 issue of Citichat.

The very international rooting of the CID policy itself raises a number of problematic questions, addressing mainly the relevance of such a policy transfer within the South African context. The use of a Western world reference point is very much in line with the neoliberal agenda adopted at the city level. As M. Farr, former CEO of the CTP, once bluntly stated:

If we want to turn Cape Town into a globally competitive city, then the benchmark for development strategies cannot be African standards, but must be first world, western standards. That's why informal traders and parking terrorists must be managed efficiently'

(Quoted in Nahnsen, 2002: 178).

In a way, the implementation of CIDs would guarantee the cities' access to the coveted world class status, thus excising them from their geographic location: the various mottos given to LED planning programmes in Johannesburg confirm this, especially the early 1990s 'Gateway to Africa' programme (Rogerson, 1996: 141), which reflected the assumption that Johannesburg was a 'frontier town', lying on the edge of the continent (Bremner, 2000: 188). The turn towards the promotion of Johannesburg as a 'World Class African City' (City of Johannesburg, 2004) probably reflects some anxiety to establish the city's position in the global hierarchy on a par with discourse on engagement with its African dimension. Such reference to 'Africanness' is notably absent from Cape Town's self-promotion, which probably reflects the difference in the 
Didier S., Peyroux E., Morange M., 2012, “The spreading of the City Improvement District model in Johannesburg and Cape Town : Urban regeneration and the neoliberal agenda in South Africa", The International Journal of Urban and Regional Research, 36(5), pp. 915-935.

racial and social structure of the city, and the city centre in particular. Interestingly, it appears since the mid-2000s that new urban references have emerged for South African cities that originate from the global South, particularly from Brazilian and South American cities: in all the fields of urban management, new models are put forward in areas that were previously the prserve of Northern models (see for instance the extensive use of the Bogota and Curitiba references in the recent implementation of the Rea Vaya Bus Rapid Transit scheme in Johannesburg). This also reflects the local adaptation and aspirations of emerging cities after an early 'copycat' period that lasted about ten years and the now global connections of city officials and private actors engaging in South-South relations, combined with the global popularity of these new models. In an interesting repetition of the situation that occurred at the turn of the century and saw the North American BID model being imported without much questioning on the South African side, the Cape Town Central CID is now considered an example for the African continent, as can be seen from Box 2.

Box 2: Spreading the Cape Town gospel
Derek Bock, chief operations officer of the Central City Improvement District, flies on
Monday to Gabon to attend the opening of its capital's first central improvement district
(CID). Also attending the three-day launch are representatives of the Independent
Development Corporation, the Mandela Bay Development Agency of Port Elizabeth, and
members of the Tshwane city council. The event is being opened by Gabon's President
Omar Bongo, Africa's longest serving ruler. Bock said Cape Town's CCID has been invited
because it was known as South Africa's strongest and most successful improvement
district. This invite is another feather in the cap of the CCID. 'I am extremely proud to be
a Capetonian and to be part of the CCID team that has changed the central city into what is
probably the safest and cleanest central city in the country.'
(...)
The CCID has been invited to advise several cities on the establishment of similar areas.
Last year, Bock spoke to 1500 delegates at the Colorado conference of the International
Downtown Association, the world's largest organization of CIDs. Andrew Boraine, chief
executive of the CTP, said: 'Cape Town is being recognized for its experience and expertise
in the management and development of business areas.'
Cape Times, 'Bock attends launch of first CID in Gabon', 16 January 2006

No one today seems to question the transfer of the formula to Gabon in the mid-2000s. It is uncertain how Cape Town could be a model for Libreville, yet this transfer will probably prove extremely interesting as a further declination and local redefinition of an international model, this time with reference to a South African success story: Andrew Boraine (Head of the CTP) has recently explained that Brazilian city managers are eager to engage with South African counterparts on matters related to urban regeneration models.

If we ask what is left in these model scenarios for the development of a specific South African tool, we discover that South African CIDs are definitely distinctive as regards their strong security component, a point much highlighted on CID websites. Security budgets are larger than in their American or European counterparts, although they vary considerably from one CID to another: from $71 \%$ in the 2001 budget of the CBD CID of Johannesburg, to $54 \%$ in the 2000 budget of the northern Sandton one (CJP, 2001; PUR, 2000). Yet, this difference can be considered a mere technical detail. The real issue regarding the transfer and adaptation of CIDs, echoes broader South African debates about the city in general and illustrates the awkwardness of the 'Third way' of managing the city implemented locally in both cities. 
Didier S., Peyroux E., Morange M., 2012, “The spreading of the City Improvement District model in Johannesburg and Cape Town : Urban regeneration and the neoliberal agenda in South Africa", The International Journal of Urban and Regional Research, 36(5), pp. 915-935.

Depoliticization v. the return of politics: South African critiques and debates around CIDs and urban regeneration

In the North American context, business improvement districts have been discussed and criticized in academic circles since the early 1990s. Most criticisms have addressed the exclusionary dimension of these schemes and, in doing so, stressed an ever-growing divide in American cities between rich and poor as well as its application to urban public space and public culture (Zukin, 1995). The privatization of public space was central in these debates, very much in line with the criticism of 'Corporate America' that was voiced around issues such as the Disneyfication of the city, a criticism broadly exported to the general public debate. When it comes to the South African case, the neoliberal discourse about CIDs praises their efficiency and, in particular, the fact that they are not the product of an inefficient and politicized way of ruling the city (one could interpret in this sense the 'lack of political will' of public authorities - see above): in Cape Town, the private consultant who wrote the CID bylaw talked of manipulative politicians whereas she described the private sector as 'pure' and independent from political fights ('the last thing you want is a politician on a CID' [F25]). Such insulation from earthly politics (Peck 2004: 394) allowed the CID formula per se to remain unquestioned for a long time [F26]. CIDs are taken for granted, which cancels out most of the debates concerning the tool itself, and shifts the blame to the municipalities in broader debates regarding the handling of city centres. These debates, in turn, bring politics back into the CID formula, in their echo of the post-apartheid context and their demands for justice for the poor.

Several issues have disrupted the smooth narrative surrounding urban regeneration programmes directly linked to CID policies in South Africa's city centres. In Cape Town's CBD, the hard line taken against the poor looking for job opportunities has been a recurrent feature since the turn of the century: the issue of street children, the homeless, vagrants and parking attendants expelled from the central CID-controlled perimeter, points to the westernized conception of what South African city centres (especially Cape Town) should be in order to become competitive at global level and have trouble engaging with characteristics (such as informality in public spaces) more prevalent in cities of the global South. NGOs as well as academics publicly and regularly denounce the strong-arm tactics used by the municipality to enforce bylaws meant to regulate behaviour in city centres [F27]: the enforcing of a micro local neoliberal urban renewal agenda equates to sorting out who has a right to be in the city centre and who does not, which sounds particularly offensive in the South African context. The backlog of the street children issue, a recurrent feature of the past ten years, offers numerous stories of expulsion by private security agents, from the centre to remote townships and squatter camps,[F28] and ensuing complex public debates often see the shifting of responsibilities from one stakeholder (CCID, CTP, municipality, the South African Police Service, etc.) to another... In this context, when the CTP has considerably altered its discourse on these issues, the position of CCID managers has been consistently clear and the enforcement of such exclusionary measures appears not only a necessity but also a right: 'The general public have a right to visit town without being mugged or harassed by militant and aggressive street children'. [F29]

In Johannesburg, CID management companies are aware of the criticisms: they generally feature prominently in business plans, but as 'misperceptions' (concerns that CIDs will result in the Local Authority reducing services further or discontinuing them; concerns that CIDs are the 'rich looking after themselves to the exclusion of the urban poor', etc.), that are faced then carefully discarded (CJP, 2001: 23). In order to soften the blow, some social tasks have even gradually been added to the business plans of CIDs, and the implementation of two residential 
Didier S., Peyroux E., Morange M., 2012, “The spreading of the City Improvement District model in Johannesburg and Cape Town : Urban regeneration and the neoliberal agenda in South Africa", The International Journal of Urban and Regional Research, 36(5), pp. 915-935.

CIDs in the inner city could be seen as a move towards more socially sensitive CIDs. In Cape Town, for instance, in addition to traditional cleaning and safety services, they have developed more socially oriented activities (such as social events for children, campaigns related to health and safety, the provision of piece jobs, etc.). Still, social activities in business CIDs appears as essentially cosmetic measures. For instance, the range of services that can be offered by Improvement Districts include 'Human Services', where CIDs can become partners with human service agencies to help address the issue of homelessness (CJP 2001: 8), in an unusual commodification of social issues dealt with at the same level as cleaning and security. In general, interviews conducted in Johannesburg within business CIDs showed that, from the private sector's point of view, CIDs are perceived as a business or profit-driven process. They respond to the need for predictability: they promote stable areas, which satisfy the requirements of the market forces in terms of property value. Many interviewees stated that CIDs are more about controlling and regulating space for economic purposes than solving social problems or promoting social policies.[F30] These alleged limitations of CIDs also imply that private-led urban regeneration projects cannot and must not deal with social issues, and that they will have to be complemented by public policies, thus sending public and private stakeholders back to their traditional roles and casting doubt on the validity of the new urban practices promoted by the neoliberal order. Housing companies implementing residential CIDs have developed a different point of view: they build on contemporary discourses about social capital and the relevance of local social relations for LED (Forrest, 2001; Peyroux, forthcoming). They also, put the emphasis on 'social contracts and building trust' in order for the residents to recover thanks to the breakdown of 'anonymity and isolation' (Adler, 2008: 23).

While the views of the private sector involved in business CIDs seem rather simple, the position of public authorities is more ambiguous due to their recent commitment to implement the developmental state at the local level.[F31] This return to social issues was particularly clear in the case of the Cape Town Central CID with the careful reconstruction of the CTP around its new manager, Andrew Boraine [F32], from 2003 onward. He was called in to put a stop to Michael Farr's previous management, and Farr was replaced under municipal pressure in 2003 (Morange and Didier, 2006b). Once in charge of the CTP, Boraine developed a new style of communication, clarified roles and responsibilities and emphasized the role of the CID in solving social issues:

\footnotetext{
'Whether living in loft apartments or on the streets, we need to treat all people humanely'; 'This city is not just about buildings, it is about the people'; 'while investment and development are essential ... the partnership's primary concern is the people of CT'; 'there must be a complete distinction between criminal activity and homelessness' [F33].
}

Despite the efforts to incorporate critiques and tackle social issues at CID level, contestation still going on in both cities reflects not just the difficult positioning of the CID tool but the difficult implementation of regeneration policies, whether implemented at CID micro level or more broadly. In Johannesburg the regulation of uses and practices in public space affecting hawkers are at the core of the debates. The Gauteng Hawkers Association has voiced strong criticisms of the CJP, in particular regarding the displacement of hawkers to specific designated areas. Beyond the issue of hawkers, there is an acknowledgement of the tension in the very nature of CIDs caught between the nature of South African urbanization processes and the transfer from a North American model, between African and First World, between chaos and order: 
Didier S., Peyroux E., Morange M., 2012, “The spreading of the City Improvement District model in Johannesburg and Cape Town : Urban regeneration and the neoliberal agenda in South Africa”, The International Journal of Urban and Regional Research, 36(5), pp. 915-935.

Urban developers and managers must be compelled to take into account the demographics of African economic activity such as trading by individuals and society as a whole, as well as the impact of migration and urbanization, before being allowed to embark on the implementation of first world 'service excellence' urban management models primarily at the expense of the poor.[F34]

\section{Conclusion}

While CIDs can be considered a very narrow entry into issues of urban regeneration as they affect cities of the global South, a careful examination of their historical trajectories once they hit the ground allows us to connect them to broader issues. It has been almost 15 years since South African cities first implemented CIDs, a tool adapted from North American experiments. CIDs can be considered as one of the tools that paved the way for the neoliberalization of urban policies and practices. Their analysis must take into consideration the fact they are a locally embedded yet transnational process (Peck, 2004: 395), for they articulate foreign influences with local practices as well as feared memories of apartheid planning and current debates around the local developmental state. But the 15-year period also offers a good demonstration of the evolution of the model, progressively bent to accommodate specific local demands for more concern with social issues, but, in essence, still remaining true to its pro-business agenda. Consequently, the interpretation of these schemes and the discourses they generate can appear contradictory at times, reflecting the complexity and contradictions in the planning visions held over time by the different stakeholders participating in these arrangements, and in particular that of the public sector, divided over the political vision driving urban development. This complexity, which is not a mere chronological layering of successive experiments but reflects a hybridization of the model as well as internal political tensions with regards to its implementation, blurs the diagnosis of a deep neoliberalization of South African cities. Nevertheless, neoliberalization has happened through the implementation of New Urban Management, and its principles are now incorporated into local practices, most notably those of the CID.

The 15-year period of CID implementation in South Africa also gave rise to fierce competition between major cities as to which one had the most efficient scheme, a policy battle mirroring old feuds (Cape Town vs. Johannesburg, etc.). The centralized management of CIDs in Cape Town is still, for instance, often compared by its proponents to the fragmentation of the schemes in Johannesburg. As the circulation continues, South African CIDs are becoming the next beacon of urban imaginaries in the international success of the formula, this time for their African neighbours, but also for cities of the emerging South as a whole: again, there is a jockeying for positions in the global business of urban regeneration, notably involving Cape Town's powerful CTP via the promotion of the CCID experiment in Cape Town. This internationalization of the South African CID model reflects the next step and the definite need for solutions tailored for cities of the South, when it comes to urban development in general and urban regeneration in particular. Andrew Boraine, head of the CTP, who presented a paper on PPPs at a recent IDA conference, explained that it was an 'attempt to situate urban management and development in the context of Cape Town as a developing city in an emerging economy, conditions somewhat different to those faced by cities in advanced industrialized nations.' (http://www.capetownpartnership.co.za/andrew-boraine-writes/, accessed in June 2011). A careful analysis of the new set of toolkits and solutions to address these issues should be able to shed light on the shifting reference models as well as the new paths of policy circulation within the global South. 
Didier S., Peyroux E., Morange M., 2012, “The spreading of the City Improvement District model in Johannesburg and Cape Town : Urban regeneration and the neoliberal agenda in South Africa", The International Journal of Urban and Regional Research, 36(5), pp. 915-935.

Sophie Didier ((sophie@ifas.org.za), French Institute of South Africa (IFAS- UMIFRE CNRS 25), Johannesburg, South Africa, Elisabeth Peyroux (elisabeth.peyroux @ univ-tlse2.fr), University of Toulouse II, Interdisciplinary Centre for Urban Studies (LISST-Cieu), National Centre for Scientific Research (CNRS), Marianne Morange (marianne.morange @ univ-parisdiderot.fr), Géographie, Université Paris Diderot, Sorbonne Paris Cité, SEDET, EA 4534, 75 013, Paris, France

\section{References}

Adler, J. (2008) eKhaya - The anatomy of an inner city residential neighborhood. In City Report 2008 Email Edition, 23-25, Trafalgar [WWW document]. URL http://www.trafalgar.co.za/cms/Downloads/InnerCityReport/Report-7.pdf (accessed 2 December 2011).

Beall, J., O. Crankshaw and S. Parnell (eds.) (2002) Uniting a divided city. Governance and social exclusion in Johannesburg. Earthscan, London.

Beavon, K. (2004) Johannesburg. The making and shaping of the city. UNISA Press, Pretoria.

Bénit, C. And P. Gervais-Lambony (2005) Globalisation as local political instrument in South African metropolitan area (Johannesburg and Ekhuruleni): the 'poor' and the 'shop window'. Transformation: Critical Perspectives on Southern Africa, 57.

Bénit-Gbaffou, C., S. Didier and M. Morange (2008) Communities, the private sector and the State: contested forms of security governance in Cape Town and Johannesburg. Urban Affairs Review 43, 691-717.

Berg, J. (2004) Private policing in South Africa: the Cape Town City Improvement Districts pluralisation in practice. Society in Transition 35.2, 224-50.

Bremner, L. (2000) Reinventing the Johannesburg inner city. Cities, 17.3, 185-93.

Brenner, N. and N. Theodore (2002) Cities and the geographies of 'actually existing neoliberalism'. Antipode, 34.3, 349-79.

Brenner, N., J. Peck and N. Theodore (2010) Variegated neoliberalization: geography, modalities, pathways. Global Networks, 10.2, 182-222.

Briffault, R. (1999) A government for our time? Business Improvement Districts and urban governance. Columbia Law Review, 99, 366-425.

CJP, (The Central Johannesburg Partnership) (2001) Central Improvement District, Business Plan.

Cook, I.R. (2008) Mobilising urban policies: The policy transfer of US Business Improvement Districts to England and Wales. Urban Studies, 45, 773-95.

Cook, I.R. (2009), Private sector involvement in urban governance: The case of Business Improvement Districts and Town Centre Management partnerships in England. Geoforum, 40.5, 930-40.

CTP (Cape Town Partnership) (2009) History of the Cape Town Partnership [WWW document]. URL http://capetownpartnership.wwc.co.za/wpcontents/uploads/2009/08/History-of-the-Cape-Town-Partneship.pdf, accessed March 2011.

de Beus, J. and T. Koelble (2001) The Third Way diffusion of social democracy: Western Europe and South Africa compared. Polikon. South African Journal of Political Studies 28. 2, 181-94.

Didier, S., M. Morange and E. Peyroux (2011) City improvement districts and 'territorialized neoliberalism' in South Africa (Johannesburg, Cape Town). In J. Künkel and M. Mayer (eds.), Neoliberal urbanism and its contestations - crossing theoretical boundaries, Palgrave Macmillan, Basingstoke. 
Didier S., Peyroux E., Morange M., 2012, “The spreading of the City Improvement District model in Johannesburg and Cape Town : Urban regeneration and the neoliberal agenda in South Africa", The International Journal of Urban and Regional Research, 36(5), pp. 915-935.

Dubresson, A. (2008) Urbanisme entrepreneurial, pouvoir et aménagement, les CID au Cap. In A. Dubresson and S. Jaglin (eds), Le Cap après l'apartheid, Gouvernance métropolitaine et changement urbain, Karthala, Paris.

Eick, V. (2007) 'Space patrols': the new peace-keeping functions of nonprofits. Contesting neoliberalization or the urban poor? In H. Leitner, J. Peck and E.S. Sheppard (eds.), Contesting neoliberalism. Urban frontiers. The Guilford Press, New York.

Fairclough, N. (2000) Language and neo-liberalism. Discourse and Society 11.2, 147-8.

Fine, B., S. Ashman and S. Newman (2010) The developmental state and post-liberation South Africa. In N. Misra-Dexter and J. February (eds.), Testing democracy: which way is South Africa going? ABC Press/Institute for a Democratic South Africa, Cape Town.

Forrest, R. (2001) Social cohesion, social capital and the neighborhood. Urban Studies, 38.12, $2125-43$.

Fraser, N. (2004) Year-end review 1. Citichat, 5 November 2004 [WWW document]. URL http://www.joburgnews.co.za/citichat/2004/nov5_citichat.stm (accessed 4 December 2011).

Guillaume, P. (2001) Johannesburg. Géographies de l'exclusion. IFAS-Karthala, Paris.

Hoyt, L. (2004) Collecting private funds for safer public spaces: an empirical examination of the business improvement districts concept. Environment and Planning B, 31.3, 36780 .

Hoyt, L. (2005) The business improvement district: an internationally diffused approach to revitalization. International Downtown Association, Washington, DC.

Hoyt, L. (2006) Importing ideas: the transnational transfer of urban revitalisation policy. International Journal of Public Administration, 29. 221-43.

Jessop, B. (2002) Liberalism, neoliberalism and urban governance. A State theoretical perspective. Antipode, 34, 2, 452-72.

Larner, W. (2003) Neoliberalism? Environment and Planning D 21, 509-12.

Leitner, L., Peck, J., Sheppard, E.S. (2007) Contesting neoliberalism. Urban frontiers. The Guilford Press, New York.

Lippert, R (2009) Signs of the surveillant assemblage: privacy regulation, urban CCTV, and governmentality. Social and Legal Studies: An International Journal 18.4, 505-22.

Lipietz, B. (2008) Building a vision for the post-apartheid city: what role for participation in Johannesburg's City Development Strategy? International Journal of Urban and Regional Research 32.1, 153-63.

Lloyd, M.G., J. McCarthy, S. McGreal and J. Berry (2003) Business improvement districts, planning and urban regeneration. International Planning Studies 8, 295-321.

Mabin, A. (2007) Johannesburg: (South) Africa's aspirant global city. In K. Segbers and S. Raiser (eds.), The making of global city regions, Johannesburg, Mumbai/Bombay, São Paulo and Shanghai, Johns Hopkins University Press, Baltimore.

McCann, E. and K. Ward (2010) Relationality/territoriality: toward a conceptualization of cities in the world. Geoforum 41.2, 175-84.

Marquardt, N. and H. Füller (2008) Die Sicherstellung von Urbanität. Ambivalente Effekte von BID auf soziale Kontrolle in Los Angeles [Making urban life safe. The ambivalent effects of BID on social control in Los Angeles]. In R. Pütz (ed.), Business improvement districts, Geographische Handelsforschung, 14, L.I.S. Verlag, Passau.

McDonald, D.A. and L. Smith (2004) Privatising Cape Town: from apartheid to neo-liberalism in the mother city. Urban Studies 41.8, 1461-84.

Michie, J. and V. Padayachee (2001) South Africa: a third way in the third world? In P. Arestis and M. Sawyer (eds.), The economics of the third way, London, Edward Elgar. 
Didier S., Peyroux E., Morange M., 2012, “The spreading of the City Improvement District model in Johannesburg and Cape Town : Urban regeneration and the neoliberal agenda in South Africa", The International Journal of Urban and Regional Research, 36(5), pp. 915-935.

Miraftab, F. (2007) Governing post-apartheid spatiality: implementing City Improvement Districts in Cape Town. Antipode 39.4, 602-26.

Mitchell, J. (2001) Business improvement districts and the 'new' revitalization of downtown. Economic Development Quarterly 15, 115-23.

Morange, M. and S. Didier (2006a) 'City' Improvement Districts vs. 'Community' Improvement Districts: urban scales and the control of space in post-apartheid Cape Town. Trialog 89, 15-20.

Morange, M. and S. Didier (2006b) Security discourses, community participation and the power structure in Cape Town, 2000-2006. Urban Forum 17.4, 59-85.

Morcöl, G. and U. Zimmermann (2006) Metropolitan governance and business improvement districts. International Journal of Public Administration, 29,1-3, 5-29.

Morris, A. (1999) Bleakness and light: inner-city transition in Hillbrow, Johannesburg. Witwatersrand University Press, Johannesburg.

Murray, M.J. (2008) Taming the disorderly city: the spatial landscape of Johannesburg after apartheid. UCT Press, Cape Town.

Nahnsen, A. (2002) Emergency on planet Cape Town - competing discourses and practices of desire and fear in a post-apartheid city. Unpublished $\mathrm{PhD}$ thesis, Oldenburg University, Germany.

Parnell, S. and E. Pieterse (1999) Developmental local government: the second wave of postapartheid urban reconstruction. Africanus 29.2, 68-85.

Parnell, S. and J. Robinson (2006) Development and urban policy: Johannesburg's City Development Strategy. Urban Studies 43.2, 337-56.

Peck, J. (2004) Geography and public policy constructions of neo-liberalism. Progress in Human Geography 28.3, 392-405.

Peck, J. and A. Tickell (2002) Neoliberalizing space. Antipode 34.3, 380-404.

Peyroux, E. (2008) City Improvement Districts in Johannesburg: an examination of the local variations of the BID model. In R., Pütz (ed.), Business Improvement Districts, Geographische Handelsforschung, 14, L.I.S. Verlag, Passau.

Peyroux, E. (forthcoming) Legitimating Business Improvement Districts in Johannesburg: a discursive perspective on urban regeneration and policy transfer. European Urban and Regional Studies, theme issue on BIDs.

PUR (Partnerships for Urban Renewal) (2000) Sandton Business Improvement District, Business Plan.

Pütz, R. (ed.) (2008) Business Improvement Districts. Geographische Handelsforschung, 14, L.I.S. Verlag, Passau.

Robinson, J. (2006) Ordinary cities: between modernity and development. Routledge, London. Rogerson, C.M. (1996) Image enhancement and local economic development in Johannesburg. Urban Forum 7.2, 139-58.

Rogerson, C.M. (2004) Towards the World-Class African city. Planning local economic development in Johannesburg. Africa Insight 34.4, 12-21.

Seekings, J. (2000) Introduction: urban studies in South Africa after apartheid. International Journal of Urban and Regional Research 24.4, 832-40.

Tomlinson, R. (1999) From exclusion to inclusion: rethinking Johannesburg's central city. Environment and Planning A 31, 1655-78.

Töpfer, E., V. Eick And J. Sambale, J. (2007) Business Improvement Districts - neues Instrument für Containment und Ausgrenzung? Erfahrungen aus Nordamerika und Großbritannien [BIDS - a new instrument for containment and exclusion? Experiences from North America and Great Britain]. PROKLA, Zeitschrift für kritische Sozialwissenschaft 149. 37, 4, 511-28. 
Didier S., Peyroux E., Morange M., 2012, “The spreading of the City Improvement District model in Johannesburg and Cape Town : Urban regeneration and the neoliberal agenda in South Africa", The International Journal of Urban and Regional Research, 36(5), pp. 915-935.

Ward, K. (2006) Policies in motion, urban management and state restructuring: the trans-local expansion of business improvement districts. International Journal of Urban and Regional Research 30.1, 54-75.

Wolf, J. (2006) Urban governance and business improvement districts: The Washington, DC BID, International Journal of Public Administration 29.1-3, 53-75

Zukin, S. (1995) The cultures of cities. Blackwell, New York.

Zunino, H.M. (2006) Power relations in urban decision-making: neo-liberalism, 'technopoliticians' and authoritarian redevelopment in Santiago, Chile. Urban Studies 43.10, $1825-46$.

\begin{abstract}
Résumé
La diffusion du modèle du CID et du principe du partenariat public-privé à l'échelle internationale pour servir des stratégies de renouvellement urbain a été lue comme conséquence de la montée en puissance de l'urbanisme entrepreneurial et comme l'avènement de pratiques et politiques néolibérales, ceci alors que la compétition économique mondiale entre les villes est plus vive que jamais. Les auteures s'attachent dans cet article à décrypter le processus de transfert et d'adaptation du modèle du CID dans deux villes du Sud, Johannesbourg et le Cap. L'argument central est que les CIDs offrent un cas d'école de l'ancrage local du néoliberalisme. Le rôle du secteur privé dans l'importation et la promotion du modèle en Afrique du Sud est souligné, et illustre la montée en puissance des techno-politiciens dans les affaires urbaines. Faisant une place particulière aux discours, les auteures analysent la façon dont les images du déclin des centres ont légitimé l'adoption du modèle. La transformation ultérieure du modèle permet par ailleurs de réfléchir aux spécificités de l'ancrage de ce modèle de «best practice » en Afrique du Sud et sa circulation à l'échelle de l'Afrique australe : alors que les CIDs nous renvoient à des questions relatives à la gestion privée des espaces publics déjà traitées dans les contextes du Nord, ils permettent également de réfléchir à la nature même du modèle de ville africaine proposé ici.
\end{abstract}

[F1] Consequently, from a methodological point of view, we will pay particular attention to the discursive justification at hand in the implementation of CIDs (on the issue of language and neoliberalization, see Fairclough (2000).

[F2] It is worth noting that this debate over the neoliberal nature of national policies in South Africa is not new: the previous phases identified above have led to discussions of this sort, particularly around the notion of 'Third Way' (see de Beus and Koelble 2001 on GEAR, Michie and Padayachee 2001 on RDP).

[F3] The CJP is a private, nonprofit company financed by major inner city businesses, which manages a large number of CIDs in the inner city. It was established in 1992 by Neil Fraser, a prominent figure of the local business community. Initially set up as a trilateral partnership between businesses, the local authority and 'the community' (represented by various Community-Based Organizations), it quickly came to represent inner city business only.

[F4] Neil Fraser in Citichat, 51, January 2003. Citichat is a monthly electronic newsletter written by the former head of the CJP.

[F5] City Improvement District Act n ${ }^{\circ} 12$ of 1997, effective in November 1999.

[F6] From the KUM website: http://www.kum.co.za/experience.php, as of November 2008. See now http://www.urbangenesis.co.za.

[F7] KUM brochure, no date.

[F8] The Sandton Business Improvement District Annual Report 2003-2004.

[F9] Based on the Urban Development Corporation (UDC) model, the JDA is an agency of the City of Johannesburg, guided by a board of directors that includes members of organized labour, business, community leaders and elected officials. 
Didier S., Peyroux E., Morange M., 2012, “The spreading of the City Improvement District model in Johannesburg and Cape Town : Urban regeneration and the neoliberal agenda in South Africa", The International Journal of Urban and Regional Research, 36(5), pp. 915-935.

[F10] The typology of CIDs in Johannesburg includes 'legislated', 'voluntary' and 'special projects'. Voluntary CIDs were developed before the City Improvement District Act No 12 of 1997 was passed and became effective in November 1999. Voluntary CIDs are still operating, often as a preliminary step before being legalized; they might also remain voluntary. In these cases, levies are not compulsory.

[F11] Cape Times, 28 February 2006, 'Retailers squeezed as rents soar in Cape CBD'.

[F12] Cape Times, 21 October 2002, 'Watershed year for city partnership with sights on R1bn target'.

[F13] See for instance Business Report, 'Johannesburg exodus continues', 25 November 1998, 'Major CBDs 'beyond point of no return' ', 15 September 2000 and 'Johannesburg's glow unlikely to return', 19 July 2001.

[F14] See, in particular, the indicators about trust and performance published by the JDA on an annual basis (Business Day, 14 November 2006, 'Joburg CBD revamp appears to be paying off') and a number of articles from Citichat and the economic press (Citichat, 14 August 2006, 'Joburg's recovery in figures'; Business Day, 15 October 2007, 'Inner-city renewal has a salutary knock-on effect' ; eProp, 28 May 2008, 'Bridge Precinct - Fully Let').

[F15] The distinction between 'areas of regeneration', called 'improvement districts' (CIDs in the inner city) that address crime and grime, and 'competitive nodes', called 'management districts' (in the Northern suburban areas) with a focus on place marketing points to this transformation of the initial formula.

[F16] See the introduction to this symposium for details of these categories.

[F17] See for the case for Cape Town 'New York or London style living in the CBD', The Saturday Argus, January 1, 2004. The original inspirations for the CCID in Cape Town were mostly drawn from New York and Coventry (CTP, 2009).

[F18] The Capetowner, 24 July 2003, 'Mr Crime and Grime becomes El CID'.

[F19] CBN Archive, October 2000, 'CID also has its problems'.

[F20] Significantly, Derek Bock received the individual achievement award of the IDA in 2007, and Andrew Boraine has joined the board of the same institution. In Johannesburg, the CJP, and now Urban Genesis, are members of the IDA.

[F21] See the References section. L. Hoyt is also part of a private consulting firm in Massachusetts.

[F22] The Association of Town Centre Management is a British equivalent to the International Downtown Association (see Ward, 2006).

[F23] The Council for Scientific and Industrial Research is a major South African Research centre.

[F24] Cape Town is a city where the socio-spatial changes brought by the end of apartheid remain scarce in the central areas, contrary to what Johannesburg experienced in the 1990s and early 2000s.

[F25] Interview, July 2004.

[F26] In Johannesburg, CIDs have only recently been targeted by hawkers associations in view of the exclusionary processes within their perimeter.

[F27] See, for instance, the Cape Town city by-law adopted in June 2006 targeting beggars: they are not allowed to touch people or follow them around 'in a manner that induces reasonable fear of bodily harm' (Cape Argus, 05 June 2006, 'Beggars crackdown blasted').

[F28] See, for instance, the 2005 round-up of 50 street children by the police in central Cape Town (Cape Times, 6 July 2005, 'Cape Town streets “purged” of street children').

[F29] Declaration of D. Bock, Security Manager for the CCID, to the Cape Times, 6 July 2005.

[F30] Interviews with CID board members, Johannesburg, 2005.

[F31] Lipietz has recently shown that this tension between pro-growth and pro-poor agendas in urban policy making is particularly true in Johannesburg due to strong internal divides within the ANC (Lipietz, 2008).

[F32] A former ANC city manager of Cape Town in the late 1990s, Boraine is also an active promoter of progressive think tanks dealing with urban issues such as the SACA (South African City Alliance) and is well connected with the academic world.

[F33] The Capetowner, 14 August 2003.

[F34] Collective email released by the South African National Traders' Alliance on the 10 October 2007. 
Didier S., Peyroux E., Morange M., 2012, “The spreading of the City Improvement District model in Johannesburg and Cape Town : Urban regeneration and the neoliberal agenda in South Africa", The International Journal of Urban and Regional Research, 36(5), pp. 915-935.

\section{CAPTIONS FOR FIGURES}

Figure 1 Three generations of CIDs in Cape Town (map created by Marianne Morange)

Figure 2 Four generations of CIDs in central and northern Johannesburg (map created by Sophie Didier, based on Bénit-Gbaffou, 2007) 